\title{
Study of Flotation Parameters for Copper Recovery from Tennantite Ore
}

\author{
Peter Solozhenkin ${ }^{1}$, Olga Ibragimova ${ }^{2}$, Elena Emelyanenko ${ }^{3}$, Julia Yagudina ${ }^{4}$ \\ ${ }^{1}$ Federal State Budgetary Establishment of a Science Research Institute of Comprehensive \\ Exploitation of Mineral Resources of the Russian Academy of Science (IPKON the RASci), Kryukovsky Tupik, 4, Moscow, 111020 Russia, \\ ${ }^{2}$ University of Dodoma, Department of Mining and Mineral Processing Engineering, P.O.Box 259, Dodoma, Tanzania \\ ${ }^{3}$ Nosov Magnitogorsk State Technical University, Department of Geology and Mineral Processing Engineering \\ 455000, Lenin prospekt, Magnitigorsk, Russia \\ ${ }^{4}$ Uchaly Mining and Concentration Complex, 453700, Gornozavogskaya st, Uchaly, Bashkortostan, Russia
}

\begin{abstract}
In the present study beneficiation of copper-pyrite ores consisting of tennantite-tetrahedrite series minerals from Southern Urals deposits were critically discussed. Intergrowth of pyrite, sphalerite, tennantite and other copper sulphides, difference in their activity and size created the considerable problems in implementation of selective flotation to obtain conditional copper and zinc concentrates. Since the demand for copper is growing constantly, the need to develop processes and technologies to treat copper resources with high level of arsenic were established. A detailed study was conducted to evaluate the effect of particle size, $\mathrm{pH}$, flotation time, collector type and addition on efficiency of tennantite flotation. It was shown that maximum copper recovery of 95,3\% was obtained at pH 12.3 by lime. It was suggested to grind up to $65.72 \%$ of $-0.074 \mathrm{~mm}$ to achieve the optimum recovery of copper and high grade of arsenic in concentrate. Overgrinding led to desliming and more loss of As in tailings. It was established that allylalkylthionocarbamates and/dialkyldithiophosphinates could be considered as prospective reagents for tennantite ore flotation.
\end{abstract}

Keywords: Refractory Copper-pyrite Ores, Flotation, Tennantite, Arsenic, Recovery

\section{Introduction}

The treatment processes for the beneficiation of copperpyrite ores consisting of tennantite-tetrahedrite series minerals along with chalcopyrite, pyrite and sphalerite are generally complex. Tetrahedrite-tennantite minerals generally occur as fine anhedral grains intermixed with or in grains of galena, sphalerite, chalcopyrite, pyrite and other sulfosalts. Members of tennantite-tetrahedrite series minerals known as fahlerz minerals, ranging from tetrahedrite, $\mathrm{Cu}_{12} \mathrm{Sb}_{4} \mathrm{~S}_{13}$, to tennantite, $\mathrm{Cu}_{12} \mathrm{As}_{4} \mathrm{~S}_{13}$, are derivatives based upon the sphalerite structure [1]-[3]. One-fourth of the metal atom sites are occupied by As, Sb and rarely Bi. The copper atoms in the pure end members are split equally in two types of sites, one of which is a four-coordinated nearly tetrahedral site, and the other a three-coordinated triangular site [4]. It has been established that tetrahedrite is accommodated in copper-lead-zinc deposits and that tennantite preferentially occurs in ores rich by copper [5], [6].

Several copper-pyrite deposits have been found in Southern Urals, Russia. It differs from other similar copper-pyrite ores by thin mutual "germinating" minerals which create considerable complexities in enrichment. For the majority of these deposits arsenic content in the ore is less than $0.3 \%$, but a group of deposits as Uzelginskoye , Uchalinskoye , Mezhozernoye can be characterized by higher content of arsenic ( up to 0.8-1 \%) [7]. Arsenic is a hazardous pollutant and most of the mining companies avoid to exploit these deposits because arsenic can become a serious environmental problem and reduce the economic value of copper resources. On the other hand since the demand for copper is growing constantly, the need to develop processes and technologies to treat copper resources from additional sources such as mine tailings, low grade deposits, industrial wastes and deposits with high impurity levels such as As and Sb will continue to increase [4].

Flotation mechanisms of tennantite-tetrahedrite series minerals are not/well understood since there are limited studies involved [8]-[10]. Laboratory and plant practices showed that tennantite and tetrahedrite do not respond well to flotation using xanthate as a collector. Tetrahedrite floats well with aerophine and mercaptan type of collectors at a $\mathrm{pH}$ value between 8 and 10 [11].

Selective separation of sulphide minerals can be achieved using a variety of collectors and modifiers to adjust surface properties [10],[12]-[14]. In practice, when treating complex sulphide ores, the combination of depressants is common, especially when separation of several valuable minerals is required for better selectivity. According to the relevant studies conducting on this issue it is evident that the most troublesome question for researchers remains the discovery the selective reagents for tennantite flotation optimization. The knowledge generated in these studies is extremely helpful in further selection of collectors with desired properties as well as in designing of new reagents schemes.

\section{Research Objectives}

The objectives of the present study are tennantite and chalcopyrite and butyl xahthate as a collector which are used in practice for copper flotation from $\mathrm{Cu}-\mathrm{Zn}$-pyrite ores of 


\section{International Journal of Science and Research (IJSR) \\ ISSN (Online): 2319-7064}

Index Copernicus Value (2013): 6.14 | Impact Factor (2014): 5.611

several deposits treating at Uchaly Mining and Concentration Complex (Southern Urals, Russia). Lime and soda ash are used as modifiers for estimation the effectiveness of flotation operation. Butyl xanthate has been established as a standard reagent for comparison the selectivity of new reagents studied.

Table 1 contains the information about sample ore characteristics related to different types of deposits in Southern Urals where 1- Uchalinskaya Cu-Zn ore; 2Uzelginskaya lower level ore; 3- Uzelginskaya upper level ore; 4- Uzelginskaya Cu-Zn lower level ore; 5- Uzelginskaya $\mathrm{Cu}-\mathrm{Zn}$ upper level ore; 6- Molodezhnaya $\mathrm{Cu}-\mathrm{Zn}$ ore; 7Ozernaya $\mathrm{Cu}$ ore.

Table 1: Samples characteristics

\begin{tabular}{|c|c|c|c|c|c|c|}
\hline \multirow{2}{*}{ № } & \multicolumn{7}{|c|}{ Head assay,\% } \\
\cline { 2 - 7 } & $\mathrm{Cu}$ & $\mathrm{Zn}$ & $\mathrm{S}$ & $\mathrm{Fe}$ & $\mathrm{As}$ & Sb \\
\hline 1 & 1,09 & 3,29 & 41,1 & 30,78 & $\mathbf{0 , 1 3}$ & 0,005 \\
\hline 2 & 1,30 & 2,76 & 21,5 & 32,05 & $\mathbf{0 , 0 5}$ & N/A \\
\hline 3 & 2,77 & 0,52 & 49,4 & 42,45 & $\mathbf{0 , 5 0}$ & 0,030 \\
\hline 4 & 1,30 & 2,76 & 21,5 & 32,05 & $\mathbf{0 , 0 5}$ & N/A \\
\hline 5 & 1,49 & 2,22 & 45,1 & 38,49 & $\mathbf{0 , 5 5}$ & 0,057 \\
\hline 6 & 1,24 & 1,59 & 28,1 & 25,87 & $\mathbf{0 , 2 5}$ & 0,013 \\
\hline 7 & 2,03 & 0,26 & 25,7 & 36,62 & $\mathbf{0 , 1 2}$ & N/A \\
\hline
\end{tabular}

Table 2 shows the names and chemical formulas of collectors studied.

Table 2: Collectors studied

\begin{tabular}{|c|c|c|}
\hline Collectors & Abbreviation & $\begin{array}{c}\text { Chemical } \\
\text { formula }\end{array}$ \\
\hline Butyl Xanthate & BX & $\mathrm{C}_{5} \mathrm{H}_{9} \mathrm{OS}_{2} \mathrm{~K}$ \\
\hline Di-isobutyl dithiophosphinate & AEROPHINE 3418A & $\mathrm{C}_{8} \mathrm{H}_{18} \mathrm{PS}_{2} \mathrm{Na}$ \\
\hline $\begin{array}{c}\text { Allyl propylthiono } \\
\text { carbamate }\end{array}$ & AERO 5100 & $\mathrm{C}_{7} \mathrm{H}_{12} \mathrm{NOSNa}$ \\
\hline
\end{tabular}

\section{Methods}

\subsection{Flotation Tests}

In the present study laboratory flotation experiments were performed using a mineral separation (MS) type laboratory flotation equipment.

\section{Results and Discussion}

\subsection{Ore mineralogy and the occurrence of tennantite}

The mineralized zones of Southern Urals deposits generally correspond with the ore types which are observed: pyrite ores with significant amounts of interstitial chalcopyrite and minor amounts of sphalerite, sulfosalts, and the fahlerz minerals; ores with subequal amounts of dark sphalerite and pyrite with chalcopyrite, sulfosalts, and fahlerz minerals; disseminated ore-dispersed pyrite with sphalerite, chalcopyrite, and tennantite in host silicates. The tennantitetetrahedrite series (fahlerz minerals) occur in all ore types at these deposits but is much more abundant in ores at
Uzelginskoye deposit, some samples of which contain $70 \%$ of copper in tennantite form [6].

Tennantite refers to the sulfosalts with complex crystal structure. The lattice contains anions $\left[\mathrm{AsS}_{3}\right]^{3-}$ similar to $\left[\mathrm{SO}_{3}\right]^{2-}$ which easily can be oxidized. Tennantite as well as tetrahedrite is the second mineral after pyrite which can produce the great number of $\left[\mathrm{SO}_{4}\right]^{2-}$ by oxidation at $\mathrm{pH} 10.7$ [15].

Tennantite has less hardness and higher fragility comparing to chalcopyrite which causes to easy over grinding and desliming in comminution. The major feature of tennantite mineralogy in such deposits is isomorphism effecting on flotation properties. The fahlerz minerals of tennantite series in Southern Urals deposits are represented by two morphological variations of tennantite. Rounded and elongated tennantite 1 occurs in middle-grained pyrite, often with association of chalcopyrite, with the size range of 1050 microns. Tennantite 2 prevails in tennantite-containing pyrite ores of Uzelginskoye deposit and occurs in association with chalcopyrite and sphalerite, bornite, and sometimes galena , in the form of veins and nests in aggregates of finegrained pyrite, performs interstitial 100-500 microns by size [16]. Intergrowth of pyrite, sphalerite, tennantite and other copper sulphides, difference in their activity and size create the considerable problems in implementation of selective flotation, obtaining conditional copper and zinc concentrates. Despite several of studies that have been done related to this issue, effective selective flotation of tennantite ores is still the subject to inyestigation.

4.2. Effect of particle size distribution on copper recovery

Chalcopyrite and tennantite ore samples were received from the mine site. The chemical analysis of samples is shown in Table 3.

Table 3: Chemical analysis of samples

\begin{tabular}{|c|c|c|}
\hline \multirow{2}{*}{ Sample } & \multicolumn{2}{|c|}{ Head assay, \% } \\
\cline { 2 - 3 } & $\mathrm{Cu}$ & $\mathrm{As}$ \\
\hline Chalcopyrite type of ore & 1,57 & 0,09 \\
\hline Tennantite type of ore & 5,55 & 1,75 \\
\hline
\end{tabular}

The major sulphides detected by X-ray diffraction were tennantite ( $88,3 \%$ ), chalcopyrite ( $5,8 \%$ ) in the tennantite ore sample. The small amount of pyrite, sphalerite were also detected. The tennantite and chalcopyrite ore samples were ground at five different grinding times 5,10,15,20 and 25 minutes. The percentage of particles below 74 microns by size was determined for 5,10,15,20 and 25 minutes, respectively. For flotation tests different conditions were explored in order to search for maximum recovery of copper. The aim of these flotation tests was to obtain the concentrate with a high grade of As and high recovery of $\mathrm{Cu}$. It has been established that butyl xanthate (BX) was uses as a collector at the dosage of $100 \mathrm{~g} / \mathrm{t}$, the optimum flotation time was 16 min. Lime was applied as a modifier with residual concentration of $280 \mathrm{~g} / \mathrm{m}^{3}$. The concentrate and tailings were submitted for chemical analysis. Figure 1 shows the 


\section{International Journal of Science and Research (IJSR) \\ ISSN (Online): 2319-7064 \\ Index Copernicus Value (2013): 6.14 | Impact Factor (2014): 5.611}

relationship between the recovery of copper and particle size. In this study the percentage of particles below 0.074 mm by size was established as a parameter to estimate particle size distribution.

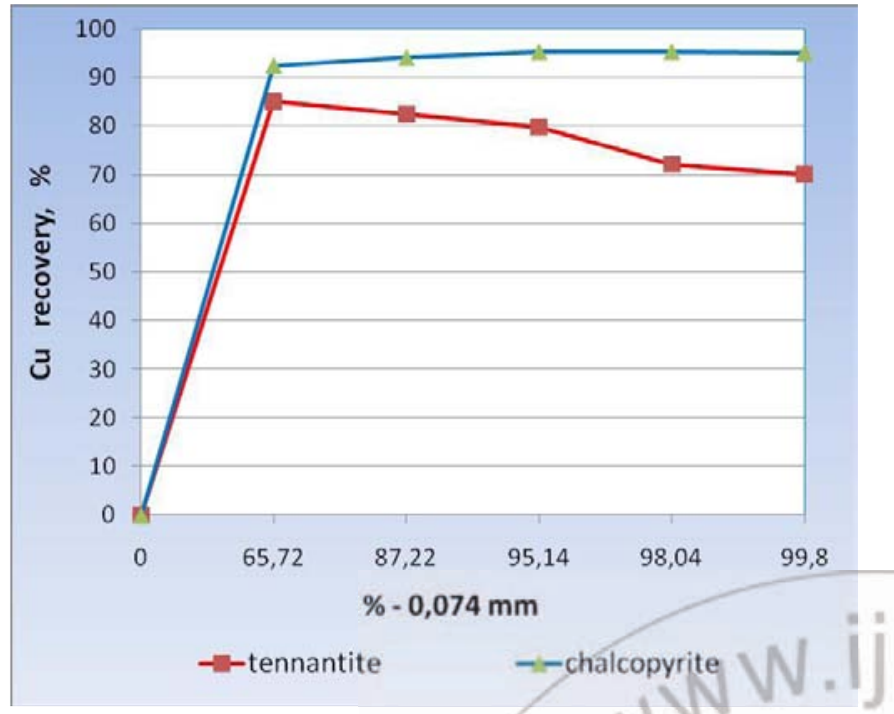

Figure 1: Recovery of copper as a function of particle size

Obviously the grinding performance significantly affects further separation results. Significant reduction in grinding size would be necessary to achieve good liberation. However, the fineness of grinding depends on the variation in hardness of minerals within the ore. Finer grinding has been expected to improve selectivity for tennantite. It has been established that the increase in the percentage of size in the feed less than $0.074 \mathrm{~mm}$ up to $65.72 \%$ has produced sufficient copper sulphide liberation and the recovery has increased up to the maximum value of $85 \%$. The further finer grinding up to $99.8 \%$ of $-0.074 \mathrm{~mm}$ led to decrease in copper recovery by about $15 \%$.

Figure 2 represents the relationship between the grade of As and the particle size.

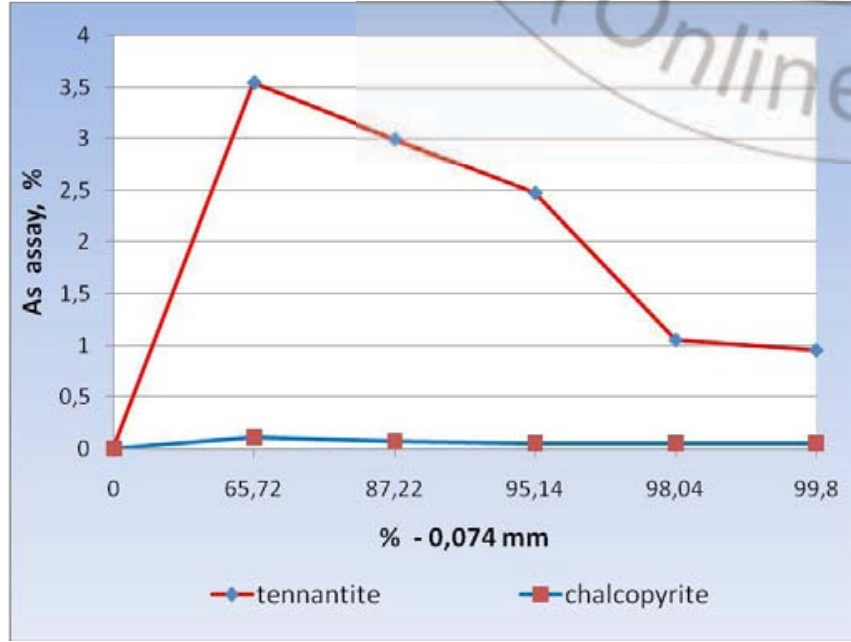

Figure 2: Grade of As as a function of particle size

It has been shown that maximum grade of As (3.5\%) was achieved at $65.72 \%$ of $-0.074 \mathrm{~mm}$ size. The finer grinding the less is the grade of As in concentrate which lead to desliming and more loss of As in tailings.

\subsection{Effect of pH modifiers on ore flotation}

In common practice the regulating reagents are using to control the adsorption of collectors in flotation operation. In order to depress zinc and iron sulfides from copper-pyrite ores, flotation process is conducted in an alkaline medium, which is created by $\mathrm{pH}$ modifiers. Discovery of optimum type and dosage of a modifier is one of effective way to enhance the flotation performance. The change in $\mathrm{pH}$ level influences on mineral surface, behavior of a collector and soluble salts in the pulp. There is the competition between soluble ions in pulp and a collector to adsorb on the mineral surface. It has been established that each $\mathrm{pH}$ reflects on different concentration of collector ions leading to maximum recovery of copper [15].

Lime is normally used as a $\mathrm{pH}$ modifier in sulphide flotation to depress pyrite. In this case, pyrite in an alkaline solution forms colloidal hydrated iron oxide $\mathrm{Fe}(\mathrm{OH})_{3}$ on the pyrite surface, thus preventing collector adsorption [11].

In present study two modifiers were used to depress pyrite soda ash and lime. Experimental results for tennantite and chalcopyrite flotation obtained in the range of $\mathrm{pH}$ are shown in Figure 3 and 4, respectively.

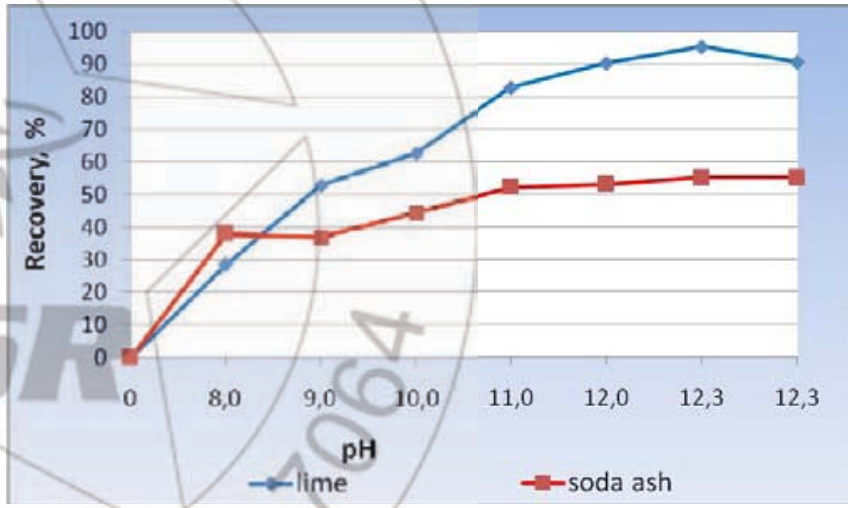

Figure 3: Recovery of copper as a function of $\mathrm{pH}$ with lime and soda ash as depressants for tennantite ore

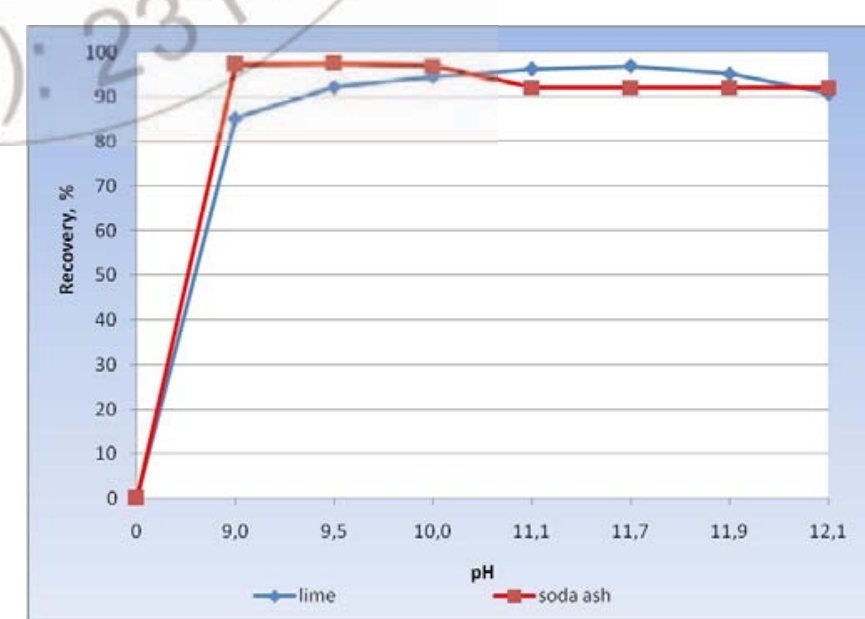

Figure 4: Recovery of copper as a function of $\mathrm{pH}$ with lime and soda ash as depressants for chalcopyrite ore

It had been established that soda ash as a $\mathrm{pH}$ modifier did not work successfully for tennantite sample. Maximum recovery of copper about $55 \%$ was reached giving the great 


\section{International Journal of Science and Research (IJSR) \\ ISSN (Online): 2319-7064}

Index Copernicus Value (2013): 6.14 | Impact Factor (2014): 5.611

loss of copper in tailings. However, the application of lime indicated that recovery of copper increased significantly to $95,3 \%$ for $\mathrm{pH} 12.3$ with the residual concentration of lime of $532 \mathrm{~g} / \mathrm{m}^{3}$. The later increase in lime dosage led to depression of tennantite and decrease in copper recovery up to $90 \%$. Copper recovery of around $97 \%$ with both soda ash and lime was achieved from chalcopyrite ore sample, indicating that chalcopyrite was easily floatable at wide range of $\mathrm{pH}$ without visible depression. According to results obtained it is evident that the type of the modifier plays the significant role on tennantite flotation. The optimum flotation was reached with $\mathrm{pH}$ range of 10.8-12.3 with lime.

\subsection{Flotation Kinetics}

There is a large number of approaches to choose the flotation reagents with desirable properties as well as to design new reagents [17]. However, it was established that available collectors for tennantite flotation showed the low level of selectivity. Therefore this study was aimed to investigate the performance of prospective reagents for tennantite. Flotation tests were carried out to obtain the optimum results with the aid of three collectors: BX, AEROPHINE 3418A and AERO 5100. Estimation of reagent schemes was conducted by comparison of relationship between the rate constant and retention time of flotation. It is known that flotation kinetics is based on assumption that the rate of flotation can be considered proportional to flotable amount of minerals.

Flotation kinetics has been taken into account using the equation proposed by Beloglazov (1) with the assumption that all particles have the same flotability.

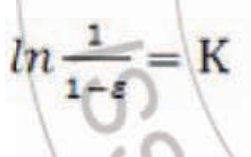

Where $\mathrm{K}$ - rate constant, $\varepsilon$-recovery of copper. Results obtained by kinetic calculations present in Figure 5.

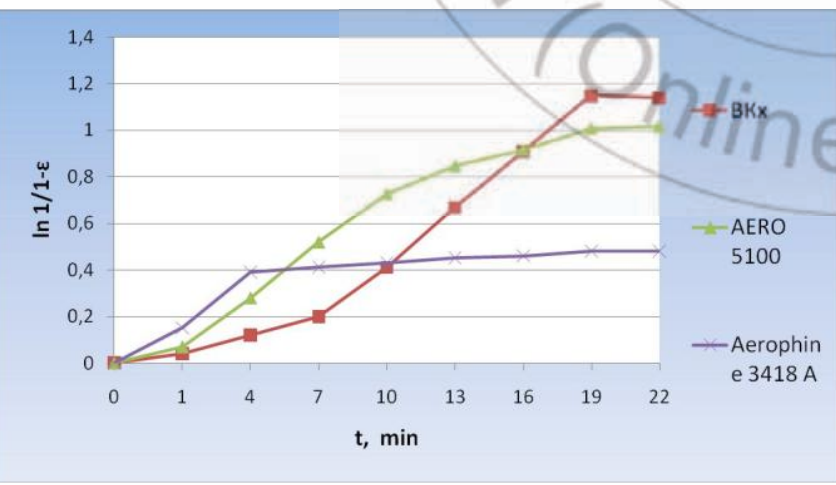

Figure 5: Kinetics of flotation of tennantite ore sample with BX, AEROPHINE 3418A and AERO 5100

It was established that tennantite flotation by BX showed the increase in rate by tenth min. Tennantite was successfully concentrated during 13 min by addition of AERO 5100 then the rate of flotation was decreased not considerably. AEROPHINE 3418A effected on flotation only the first four min and the further increase in rate was not considered. It was evident that AERO 5100 and AEROPHINE 3418A started acting at the beginning of flotation operation.
According to studies conducted these reagents can be proposed as prospective collectors for tennantite flotation .

\section{Future Scope and Implications of the Study}

Taking into account the large number of parameters influencing on tennantite flotation as well as its mineralogy the real flotation process is considered quite complicated. Viewed from the latter perspective it seems that deeper studies should be conducted revealing the mechanism of adsorption of reagents on the mineral surface of tennantite. Knowledge generating in these studies can be useful for greater understanding of current problems and help in improvement in product quality. Nevertheless the way to enhance the flotation performance of tennantite is still under investigation.

\section{Conclusions}

Copper-pyrite ores consisting of tennantite-tetrahedrite series minerals from Southern Urals deposits, Russia are charäcterized by thin mutual "germinating" minerals which create considerable complexity in enrichment. The major feature of tennantite minerology in such deposits is isomorphism effecting on flotation properties. Studies conducted to evaluate the effect of particle size, $\mathrm{pH}$, flotation time, collector type and addition on efficiency of tennantite flotation showed that maximum copper recovery of $95,3 \%$ was obtained at $\mathrm{pH} 12.3$ by lime. It was suggested to grind up to $65.72 \%$ of $-0.074 \mathrm{~mm}$ to achieve the optimum recovery of copper and high grade of arsenic in concentrate. Overgrinding led to desliming and more loss of As in tailings. It was established that allylalkylthionocarbamates and dialkyldithiophosphinates could be considered as prospective reagents for tennantite ore flotation.

\section{References}

[1] B.J. Wuensch.The crystal structure of tetrahedrite, Cu12Sb4S13. Zeitschriftftir fur Kristallographie, I 19,pp 437-453, 1964.

[2] B.J.Wuensch. Refinement of the crystal structure of binnite, Cu12As4S13. Zeitschrift fur Kristallographie, 123, pp l-20, 1966.

[3] B.J.Wuensch.Determination, relationships, and classification of sulfide mineral structures. In $\mathrm{P}$. $\mathrm{H}$. fubbe. Ed..Sulfide Mineralogy, Vol. I, pp l-43. Mineralogical Society of America, 1974

[4] J. Miller, J.Craig. Tetrahedrite-tennantite series compositional variations in the Cofer Deposit, Mineral District, Virginia,American Mineralogist, Volume 68, pp 227-234, I983

[5] E. Spiridonov. About types and variations of fahlerz minerals and rational nomenclature of minerals. New data about minerals.AS USSR.Mineral Museum by Fersman,M;Nauka, issue 32, pp 128-146, 1985

[6] E. Spiridonov, M. Maleev,V. Kovachev, I. Kulikova, G .Nazmova, S. Filimonov. Minerals of Fahlore group: Indicators of Ore Genesis // Bulgarian Geological Society, 80-th Anniversary. Proceedings of the Jubilee 


\section{International Journal of Science and Research (IJSR) \\ ISSN (Online): 2319-7064 \\ Index Copernicus Value (2013): 6.14 | Impact Factor (2014): 5.611}

International Conference. Bulgarian Geological Society. Sofia: pp 79-82, 2005.

[7] Seravkin, P.Pirozhok, V. Skuratov. Mineral resources of Uchaly mineral processing plant/ Ufa, BBP, 328p, 1994

[8] D.Fornasiero, C.Fullston, J.Ralston. Separation of enargite and tennantite from non-arsenic copper sulfide minerals by selective oxidation or dissolution, International Journal of Mineral Processing, 61, No. 2,p 109, 2001.

[9] L.Smith, W. Bruckard. The separation of arsenic from copper in a Northparkes copper-gold ore using controlled-potential flotation, International Journal of Mineral Processing, 84,p 15, 2007.

[10]Gul A., G.Bulut, A.Sirkeci.Beneficiation of arsenic bearing complex sulphide ore by flotation ,Physicochem. Probl. Miner. Process. 49(1), pp 203-212, 2013

[11] S.M. Bulatovic. Handbook of flotation reagents: chemistry, theory and practice, volume 1: Flotation of sulfide ores , Elsevier B.V., Amsterdam, 2007.

[12] T.Yamamoto. Mechanism of depression of pyrite and sphalerite by sulphite, Complex sulphide ores, ed. M..J. Jones, London, Institute of Mining and Metallurgy, p $71,1980$.

[13] V.A. Bocharov, V.A. Ignatkina, A.A. Kayumov. Fahl Ore Flotation. Journal of/Mining Science, vol 51, №3, pp 573-579, 2015

[14]H. Kazutoshi,W.Tongamp and A.Shibayama Investigation of Flotation Parameters for Copper Recovery from Enargite and Chalcopyrite Mixed Ore, Materials Transactions, Vol. 53, No. 4 pp. 707- 715, 2012

[15] E.Emelyanenko, J.Yagudina.Comprehensive approach in exploitation of refractory ores from copper-pyrite deposits. Proceedings of International Conference Plaksin Reading, Alma-Aty, pp 265-268, 2014

[16] M. Saharova. Principle questions of isomorhpizm and genesis of fahlerz minerals. Geology of ore deposits.№1, pp 23-40, 1966

[17] V. Ryaboy. Problems in application and design of new reagents in Russia. Non-ferrous Metalls Journal, №3, pp 7-14, 2011

\section{Author Profile}

Peter Solozhenkin is an outstanding scientist, who received the MS degree in Mineral Processing Engineering from the Irkutsk Mining Metallurgical Institute in 1957.During 1975-1989 he was a VicePresident of the Tajik Academy of Science. Now he is working in IPCON, Russia. His research interests are devoted to Complex Exploitation of Mineral Resources and Computer Modeling of Flotation Processes. He is the author of 17 books, several hundreds of papers, patents and articles.

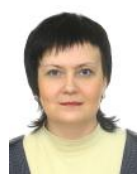

Olga Ibragimova received the MS degree in Mineral Processing Engineering from the Moscow Institute of Steel and Alloys, Russia in 1986. During 1986-1994 she stayed in Ore Dressing Laboratory, Institute of Chemistry, Tajik Academy of Science to study the phenomenon of the effect of combination of sulfur-containing collectors on non-ferrous ores flotation using spectroscopic methods. Then she has been an associate professor at the Samara
State Technical University, Russia, over the past 15 years. Presently, she is teaching at the University of Dodoma, Tanzania. Current research interests include Computer Modeling of Chemical Compounds and Processes.

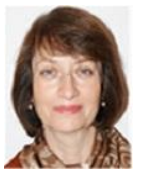

Elena Emelyanenko graduated from the Nosov Magnitogorsk Mining University, Russia in 1979 (Mineral Processing Engineering). During 1979-1999 she worked as an senior engineer in scientific research laboratory, Kazakhstan. From 2005 she is an associate professor at the geology and mineral processing department. Her scientific interests include Comprehensive Beneficiation of Refractory Copper-pyrite Ores by aid of Geotechnology.

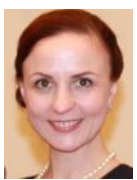

Yagudina Julia graduated from the Nosov Magnitogorsk State Technical University, Russia in 2000, specialty Mineral Processing Engineering. During 2001-2007 she stayed in Uchaly Mining and Concentration Complex as an engineer. Presently, she is a Chief of central research laboratory at Uchaly Mining and Concentration Complex. Her current research interests are devoted to effective beneficiation of refractory copper ores from Southern Urals deposits.

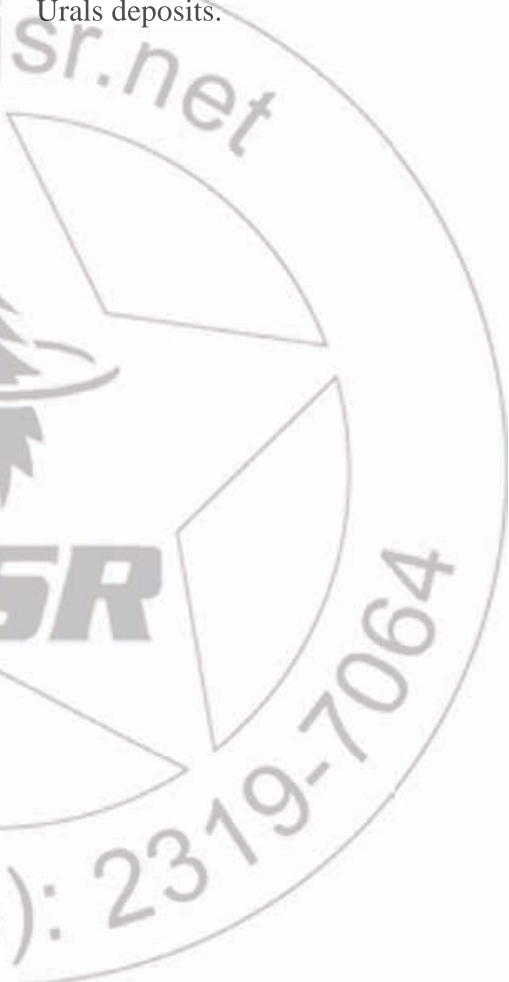

